\title{
A Histochemical Study of Mucoid Cells in the Pars Distalis of the Human Hypophysis '
}

\author{
JAMES L. CONKLIN \\ Department of Anatomy, The University of Michigan, Ann Arbor, Michigan
}

\begin{abstract}
Sections of the human hypophysis were fixed in either formalin or Bouin's fluid and stained by a variety of mucoid and acid stains in order to demonstrate the staining characteristics of the mucoid cells of the pars distalis.

Five types of mucoid cells were revealed and designated as cell types III, IV, V, VI and IX according to the classification system of Ezrin. Cell types III, IV, $V$ and VI were present throughout the pars distalis while cell type IX was observed only in the posterior zone.

The cells were tinctorially distinguished by the PAS-orange G affinity of the type III cell, the alcian blue-PAS reactivity of the type IV cell, the alcian blue staining of the type V cell and the affinity of the type VI cell for alcian blue-PAS-orange G. Cell type IX was recognized by the affinity of its cytoplasmic granules for most of the stains employed. Modified and degranulated forms of these cells were observed and are also described.
\end{abstract}

In a previous paper (Conklin, '66) some of the factors contributing to the confusion surrounding hypophyseal cytology were reviewed. This discussion of interpretation of pituitary cytology is applicable not only to the acidophilic and chromophobic cells (Conklin, '66) but also the mucoid cells.

In the present investigation, a variety of staining procedures was employed to demonstrate the staining characterisics of the mucoid cells of the human hypophyseal pars distalis. In this way it was hoped that the identity and characteristics of various mucoid cell types could be definitively established.

\section{MATERIALS AND METHODS}

The material studied and the composition of some of the stains employed have been described (Conklin, '66). The remainder are summarized below and in table 1.

Aldehyde fuchsin was prepared with basic fuchsin (C.I. 42500) according to the method of Gomori ('50). Aldehyde thionin was prepared as reported by Ezrin and Murray ('63) with thionin obtained from the Coleman and Bell Co. (Lot no. 61105) and Chroma (C.I. 52000).

The reagents for the colloidal iron and PAS procedures were prepared as described by Mowry ('58).

Alcian blue 8GX (C.I. 74240) was employed as an $0.1 \%$ solution in $95 \%$ alcohol or $3 \%$ acetic acid. Acidified resorcin fuchsin was employed as described by Krutsay ('60). Oxidizing procedures were utilized as called for in various techniques. In addition, sections were stained without prior oxidation.

The oxidizing procedures employed were:

1. Lugol's solution: Weigert's variation (Humason, '62), for ten minutes followed by a ten minute bleach in $5 \%$ sodium thiosulfate; 2 . periodic acid: $0.5 \%$ periodic acid in $70 \%$ alcohol, for ten minutes; 3 . performic acid: generated by combining 90 $\mathrm{cm}^{3} 98 \%$ formic acid, $10 \mathrm{~cm}^{3} 30 \%$ hydrogen peroxide and $1 \mathrm{~cm}^{3}$ concentrated sulfuric acid two hours prior to use, for five minutes; 4 . acidified potassium permanganate: $0.5 \%$ sulfuric acid and $0.5 \%$ potassium permanganate $(1: 1)$, for two minutes followed by a one minute bleach in $2 \%$ potassium metabisulfite.

In contrasting the results obtained with the various procedures the criteria described previously (Conklin, '66) were again employed.

\section{OBSERVATIONS}

An attempt was made to identify all the cells in the pars distalis and to describe the tinctorial and morphological characteristics of each type of cell. The findings were compared with those in earlier investiga-

\footnotetext{
1 Research supported by grant HD 00557 from $\mathrm{Na}$ tional Institute of Child Health and Human Development, National Institutes of Health.
} 
TABLE 1

Methods

\begin{tabular}{ll}
\hline Periodic acid Schiff (PAS) & Mowry's modification ('58) \\
Alcian blue, aldehyde fuchsin & Adams and Swettenham ('58) \\
Alcian blue, PAS, orange G & Gomori ('50) \\
Aldehyde fuchsin, Masson trichrome & Elftman ('59) \\
Aldehyde fuchsin, PAS, orange G & Romeis ('40) \\
Aldehyde fuchsin, Romeis counterstain & Paget and Eccleston ('60), \\
Aldehyde thionin, PAS, orange G & Ezrin and Murray ('63) \\
Colloidal iron, PAS, orange G & Ezrin et al. ('58) \\
Herlant's tetrachrome & Herlant ('60) \\
Resorcin fuchsin & Krutsay ('60) \\
\hline
\end{tabular}

tions, and an effort was made to ascertain reasons for discrepancies.

The system of Ezrin ('63) was used for designating the several cells. In this system the chromophilic cells are indicated by Roman numerals I-VIII, definitive acidophils being types I, II, and VIII and mucoid cells being types III-VII. The staining reactions of nine cells are summarized in table 2, type IX being a mucoid cell found only in the posterior zone of the pars distalis (Conklin, '66).

\section{Anterior zone mucoid cells}

Upon evaluation of the staining reactions (table 2) it was evident why many investigators failed to make a distinction between the four cell types. No mucoid stain was exclusively specific for a single cell type. In addition, the staining reactions were influenced by pretreatment of the tissue sections. This was illustrated by staining with aldehyde fuchsin. No oxidation or oxidation in Lugol's solution or periodic acid before aldehyde fuchsin gave similar results. The only difference was the increased intensity of the staining which occurred when oxidation was employed. After performic acid or permanganate oxidation, staining with aldehyde fuchsin was even less precise and various acidophils were also stained. Similar nonspecificity was also exhibited by alcoholic alcian blue. Aqueous alcian blue was more specific after performic acid treatment of the tissues as was aldehyde thionin following permanganate oxidation. Resorcin fuchsin yielded results which were comparable to those obtained with aldehyde fuchsin. Three of the four mucoid cell types were stained by the PAS reaction.
The aldehyde thionin-PAS-orange $\mathrm{G}$ techque gave variable results. Staining with aldehyde thionin was inconsistent. Thionin obtained from Chroma gave the most intense staining when a suitable stain was obtained. The intensity of staining with either aldehyde thionin or colloidal iron was never as great as that exhibited by other procedures. Also, the results after aldehyde thionin-PAS-orange $\mathrm{G}$ were found to be dependent on the concentration of sulfuric acid employed in the oxidizing solution (table 3 ).

The most specific staining of mucoid cells, which also resulted in distinct color difference, was achieved by the use of the combined performic acid-alcian blue-PASorgange $\mathrm{G}$ procedure. The basis for the specificity was (a) the PAS-orange $G$ affinity of the type III cell, (b) the alcian bluePAS reactivity of the type IV cell, (c) the unique staining the type $\mathrm{V}$ cell by alcian blue and (d) the affinity of the type VI cell for alcian blue, PAS and orange G (figs. 22-25).

\section{Description of cell types}

Cell type III. The type III cell presented the characteristics of an acidophilic-mucoid cell (figs. 2-4). The cells occasionally occurred in clusters in the central area of the gland but were most frequently present as scattered, individual cells in the posterior part of the anterior zone. Typically, the nuclei were eccentric and contained a prominent nucleolus. Chromatin varied from sparse to dense and was usually lightly stained. The cells were round or oval and the diameter ranged from 20-25 $\mu$. The intracytoplasmic granules were numerous and varied in size. Cytoplasmic vacuoles were rarely observed and the 
PITUitary MUCOID CELLS

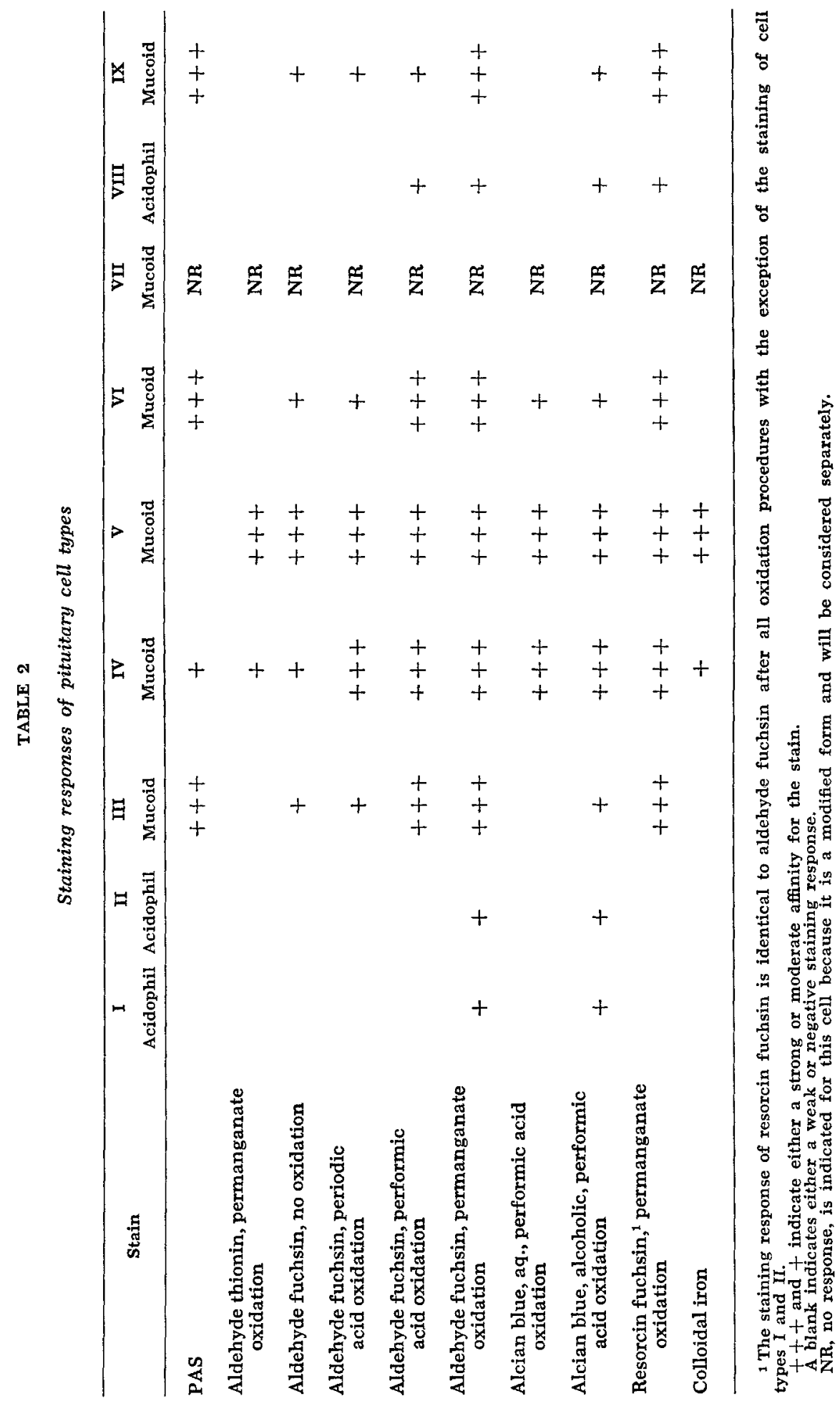




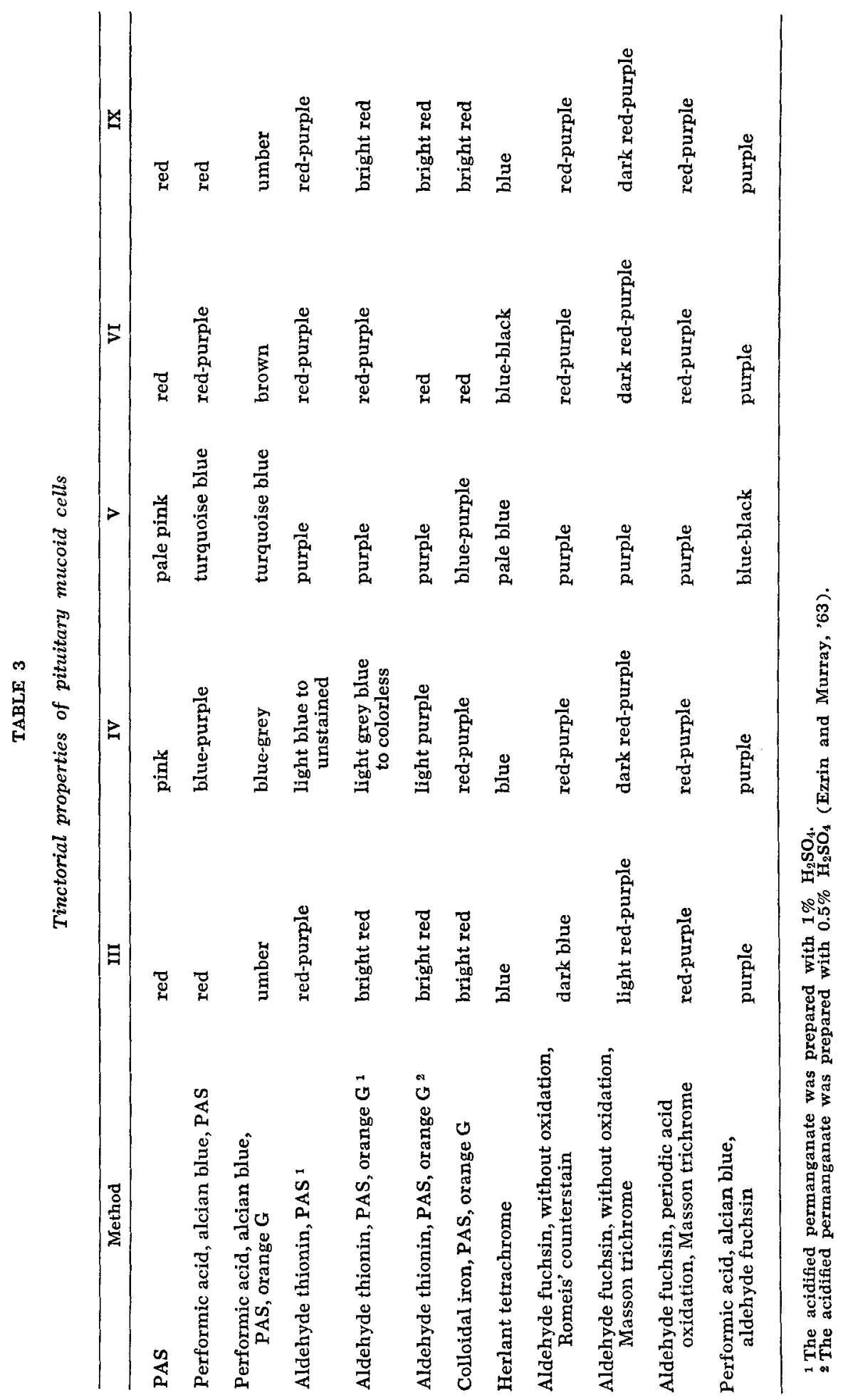


dense granulation of the cell prevented observation of a juxtanuclear zone. The cells were present in pituitaries from subjects of all ages. In summary, the type III cell contained cytoplasmic granules which were strongly PAS positive while the cytoplasm exhibited a strong affinity for orange $G$ and light green.

Cell type IV. The type IV cells contained granules which were stained by both mucoid and acid stains (figs. 8-10). They occurred most frequently in the inferior and anterior areas of the gland and were rarely present in the acidophil zone. The cells, about 18-22 $\mu$ in diameter and usually oval in shape, occurred in groups and were often mixed with type III and type VI cells. The nuclei were eccentric, contained a prominent nucleolus and exhibited a coarse chromatin pattern. Large vacuoles were often persent in the cytoplasm (fig. 10). In summary, the type IV cell was characterized by numerous granules which were stained by both acidophilic and mucoid stains. Specific identification of the cell was possible because of the weak staining of its granules by the PAS reaction.

Cell type V. The type V cells (figs. 1114) occurred throughout the gland but were least frequent in the inferior and anterior margins of the anterior zone.

While many of the cells were small, 12$15 \mu$ in diameter, others were $20-25 \mu$ in diameter. They varied in shape from round to pyramidal. They occurred frequently as single, scattered cells interspersed between other cell types except in the junctional area of the anterior and posterior zones. In this region, the cells were quite numerous and were clumped together in irregulare groups. After the colloidal iron and aldehyde thionin procedures, scattered, coarse purple granules and vesicles were prominent in the cytoplsam (fig. 13). This was in contrast to the staining after alcian blue when fine granules were colored a brilliant, turquoise blue (fig. 14). Most of the large, alcian blue positive cells were unstained by aldehyde thionin and colloidal iron. The variable appearance of the stained material suggested that different substances were being stained.

The type V cell was identified by its strong affinity for most mucoid stains, ex- cept PAS, and lack of affinity for acid dyes. Of all the mucoid cells this was the only cell type which was not also acidophilic and was therefore a "pure" mucoid type.

Cell type VI. The type VI cell was almost identical in appearance to the type IV cell (figs. 15-17). Both cell types were of the same size and shape. They exhibited similar nuclear and cytoplasmic characteristics with regard to chromatin, granules and vacuoles. The cells differed only in distribution within the gland and the tinctorial properties of the granules after certain stains. The type VI cells were most frequent in the superior and central areas of the gland. They were less frequent in the inferior and anterior areas and rarely occurred in the acidophil zone. The type VI cell could be identified because its granules were moderately stained by the PAS reaction, alcian blue and orange $G$. This cell type was classified as an acidophilicmucoid cell.

\section{Modified and degranulated cells}

In the modified type III cell, the cytoplasm was devoid of granules except in a juxtanuclear position (fig. 6). The granules were stained by aldehyde fuchsin, aldehyde thionin, alcian blue or PAS. After an alcian blue-PAS sequence they were alcian blue positive.

The degranulated type III cell was identified by the light green or pale blue staining of the cytoplasm (fig. 7). In all other properties it was similar to the modified and typical type III cells.

The modified type IV cell contained a few scattered granules and numerous vesicles (fig. 10). Both the granules and the vesicles exhibited the same staining characteristics as the typical type IV cell. Some degranulated type IV cells could be identified by morphological features. However, it is doubtful that all degranulated cells of this type were identified.

Degranulated type V cells, if present, were not identified. Partially degranulated cells of this type were observed in one gland and were identified by the tinctorial properties of the granules.

The type VI cell exhibited two altered forms. In the first, sparse granules and vacuoles were present in the cytoplasm 
(figs. 17-19). These exhibited staining properties similar to the granules of the unmodified cell. Many degranulated and partially granulated cells were also observed. The degranulated cells were slightly larger than the granulated type VI cell but other characteristics were similar.

\section{Posterior zone mucoid cells}

In adult pituitaries, mucoid cell types III, IV, V and VI were present in the posterior zone (figs. 26-29) as wall as a type designated as cell type IX. In the pituitaries of a child and a fetus, most of the cells in the posterior zone were of the type IX variety.

Cell type IX. Morphologically, cell type IX resembled the type IV and type VI cells (figs. 26-28). It was usually oval in shape with an eccentric nucleus. It was an acidophilic-mucoid cell (tables 2,3 ). It was similar in some staining properties to the type III cell and in others to cell types IV and VI. It was this duality of properties which revealed the type IX cell since it demonstrated no unique histochemical properties. Type IX cells were not observed in the anterior zone although the lack of unique staining properties may have prevented their recognition.

\section{DISCUSSION}

In the present study, five types of mucoid cells have been found in the pars distalis. Four of these cells were in the anterior zone and were also variably present in the posterior zone. The fifth mucoid cell (type IX) was observed only in the posterior zone of the pars distalis. The correlation between the cells observed in this study and those previously reported is presented in table 4. Not included in table 4 is the cell designated as type VII by Ezrin ('63). The cell is a modified type III cell and probably corresponds to the Crooke-Russell cell (Crooke, '35).

In comparing the staining properties of the five cell types it was apparent that specific staining of the four anterior zone mucoid cells was achieved only after two techniques: colloidal iron-PAS-orange $G$ (Ezrin et al., '58) and alcian blue-PASorange G (Adams and Swettenham, '58; Pearse and Van Noorden, '63). Techniques utilizing aldehyde fuchsin (Elftman, '59) or aldehyde thionin (Ezrin and Murray, '63) did not selectively color all of the cell types. The same limitation followed the use of the Herlant ('60) tetrachrome procedure. The aldehyde thionin technique did produce selective staining when the oxidizing agent was modified (see table 3 ) as suggested by Elftman ('59). Of the methods that were selective, the alcian blue-PAS-orange $\mathrm{G}$ technique produced the most intense and most consistent staining.

Fand ('55) reported that the posterior zone cells differed in enzymatic activity from cells of the anterior zone. Other investigators (Pearse, '56; Purves and Bassett, '63) have questioned this view. In this study, it was observed that the cells of the posterior zone were variable in type. Typical anterior zone cells were often observed in this area in adult pituitaries (figs. 26-29). A fifth cell type was also observed in this region in all pituitaries. This cell exhibited histochemical properties that were similar in one or more respects to those of cells in the anterior zone. It is possible that the type IX cell was observed by Fand and not by Pearse or Purves and Bassett. The technique employed by the latter investigators would not distinguish the type IX cell from other mucoid cell types.

In the present study mucoid cells were observed in the pituitaries of subjects of all ages. This is in contrast to the report of Swanson and Ezrin ('60) who observed no delta (type V) cells in pituitaries of subjects under ten years of age. Midgley ('63) found anti-LH fluorescent cells in pituitaries of children and newborn infants as well as subjects of other ages. The LH cells corresponded to the turquoise-colored, alcian blue positive cells (type V) (figs. 11-14). The failure of Swanson and Ezrin to demonstrate these cells in young subjects may be because of the technique employed. Not all of the type V cells are demonstrated by the colloidal iron or aldehyde thionin procedures. The reasons for this are not clear. The fact that Midgley demonstrated fluorescence in degranulated type $V$ cells suggests that the granules seen after histochemical procedures are either a particular form of the hormone or a "carrier" substance. 
PITUITARY MUCOID CELLS

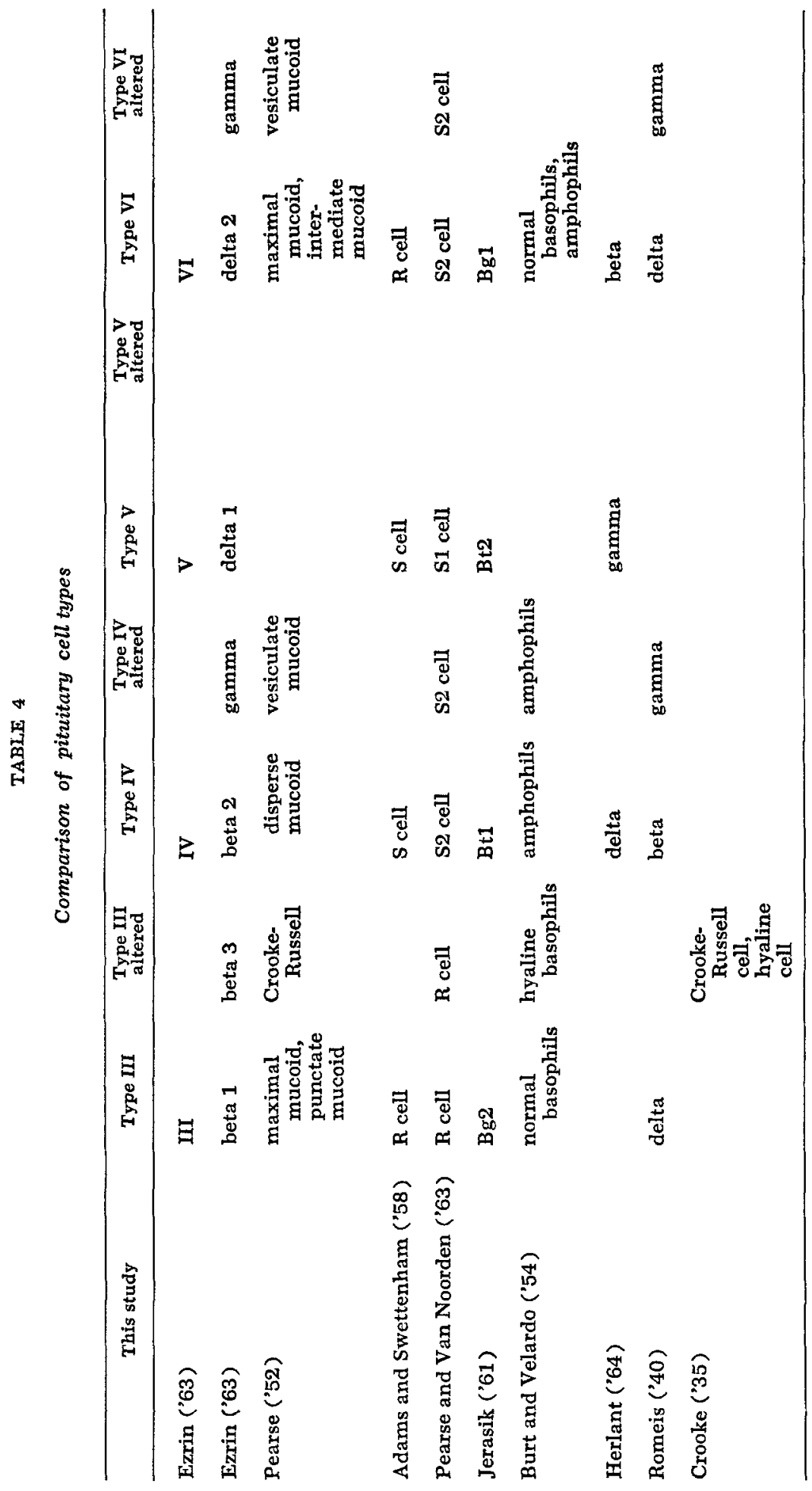


All immunofluorescent studies have localized ACTH in a mucoid cell type. Pearse and Van Noorden ('63) designated this cell as the $R 2$ cell because of its tinctorial properties after the alcian blue-PAS-orange $G$ procedure. The modified forms of the $R 2$ cell are the Crooke-Russell cell and the Crooke hyaline cell. These cells correspond to the type III and modified type III cells. As Pearse noted, the properties of the granules undergo changes when the cells are modified; they no longer stain with PAS and are alcian blue positive.

The source of the gonadotropic hormone, $\mathrm{LH}$ (ICSH), has been identified as the S 1 (type V) cell by Midgley ('63). Herlant ('64) and Pearse and Van Noorden ('63) have attributed LH secretion to a PAS positive cell. In vitro studies of the PAS reactivity of $\mathrm{LH}$ are in agreement with this conclusion (Fand and Thorell, '62). The weak PAS reactivity of the LH-cell suggests that the hormone may not be demonstrated in situ by histochemical methods.

The sources of FSH and TSH have been tentatively identified. Cruikshank and Currie ('58) localized TSH in one of the mucoid cells. Koffler and Fogel ('64) localized FSH in one of the aldehyde fuchsin positive cells. The $\mathrm{S} 2$ cell described by Pearse and Van Noorden contains granules which are both PAS and alcian blue positive. In the present study, it was noted that after the alcian blue-PAS or alcian blue-PAS-orange $\mathrm{G}$ procedures the $\mathrm{S} 2$ cells could be divided into two distinct subtypes (table 3, figs. 22-25). Rather than transitional types, these cells are the probable sources of FSH and TSH. Since the type IV (S 2) cell is more numerous in fetal pituitaries (unpublished observation) it is the probable source of TSH. The type VI (S 2) cell is more prevalent in adults, especially postmenopausal women, and may be the source of FSH.

For the present, the function of the type IX cell is unknown. Its presence in the region comparable to the pars intermedia of other species is suggestive of a comparable function.

\section{ACKNOWLEDGMENTS}

The author is indebted to Mrs. Lana Brock and Mrs. Constance Miller for assist- ance in preparation of the material and manuscript.

\section{LITERATURE CITED}

Adams, C. W. M., and K. V. Swettenham 1958 The histochemical identification of two types of basophil cells in the normal human adenohypophysis. J. Path. Bact., 75: 95-103.

Burt, A. S., and J. T. Velardo 1954 Cytology of the human adenohypophysis as related to bioassays for tropic hormones. J. Clin. Endocr., 14: 979-996.

Conklin, J. L. 1966 The identification of acidophilic cells in the human pars distalis, Anat. Rec., 156: 347-360.

Crooke, A. C. 1935 A change in basophil cells of the pituitary gland common to conditions which exhibit the syndrome attributed to basophil adenoma. J. Path. Bact., 41: 339-349.

Cruickshank, B., and A. R. Currie 1958 Localization of tissue antigens with the fluorescent antibody techniques: Application to human anterior pituitary hormones. Immunol, 1: 1326.

Elftman, H. 1959 Aldehyde-fuchsin for pituitary cytochemistry. J. Histochem., 7; 98-100.

Ezrin, C. 1963 In: Discussion Generale. Cytol ogie de l'adenohypophyse. Ed. by J. Benoit and C. Da Lage. Paris. Editions of C.N.R.S., p. 346. 1964 The pituitary gland. Ciba Clinical Symposia, 16: 71-100.

Ezrin, C., H. E. Swanson, J. G. Humphrey, J. W. Dawson and W. D. Wilson 1958 The delta cell of the human adenohypophysis: its response to acute and chronic illness. J. Clin. Endocr., 18: 917-936.

Ezrin, C., and S. Murray 1963 The cells of the human adenohypophysis in pregnancy, thyroid disease and adrenal cortical disorders. Cytologie de l'adenohypophyse. Ed. by J. Benoit and C. Da Lage. Paris. Editions of C.N.R.S., pp. 183200.

Fand, S. B. 1955 The histochemistry of the human pituitary body. I. Preliminary report, including a differentiation between basophils of the anterior and posterior lobes. J. Clin. Endocr., 15: 685-692.

- 1961 Glandular epithelial cells in the human pars nervosa: Histochemistry, distribu. tion, classification and possible clinical significance. Am. J. Clin. Path., 35: 210-221.

Fand, S. B., and B. Thorell 1962 Spectrophotometry of the periodic acid-Schiff reaction with pituitary hormones in vitro and in histological sections. J. Cell Biol., 13: 239-247.

Gomori, G. 1950 A specific stain for elastic fibers. Am. J. Clin. Path., 20: 665-666.

Herlant, M. 1960 Etude critique de deux techniques nouvelles destinees a mettre en evidence les differentes categories cellulaires presentees dans la glande pituitaire. Bull. Micr. appl., 10: 37-44.

1964 The cells of the adenohypophysis and their functional significance. In: Internat'1 Rev., Cytol., Ed. by G. H. Bourne and J. F. 
Danielli. Academic Press, New York, 17: 299382.

Humason, G. H. 1962 Animal Tissue Techniques. W. H. Freeman and Co., San Francisco.

Jirasek, J. E. 1961 Cytochemical examination of the human hypophysis during pregnancy. Acta Histochem., 12: 319-329.

Koffler, D., and M. Fogel 1964 Immunofluorescent localization of LH and FSH in the human adenohypophysis. Proc. Soc. Exp. Biol. Med., 115: 1080-1082

Krutsay, M. 1960 A versatile resorcin-fuchsin formula: I. Combined with formaldehyde, II. Used after periodic acid, III. Used after $\mathrm{HCl}$ hydrolysis. Stain Tech., 35: 283-284.

McNary, W. F., Jr. 1961 Histochemical inves tigation of the tubular glands of the pars nervosa of the human hypophysis. Anat. Rec., 139: 413-419.

Midgley, A. R., Jr. 1963 Immunofluorescent localization of human pituitary luteinizing hormone. Expt1. Cell Res., 32: 606-609.

Mowry, R. W. 1958 Improved procedure for the study of acidic polysaccharides by Muller's colloidal (hydrous) ferric oxide and its combination with the Fuelgen and the periodic acid Schiff reactions. Lab. Invest., 7: 566-576:
Paget, G. E., and E. Eccleston 1960 Simultaneous specific demonstration of thyrotroph, gonadotroph and acidophil cells in the anterior hypophysis. Stain Tech., 35: 119-122.

Pearse, A. G. E. 1952 The cytochemistry and cytology of the normal anterior hypophysis investigated by the trichrome-periodic acid Schiff method. J. Path. Bact., 64: 811-826.

1956 The esterases of the hypophysis and their functional significance. J. Path. Bact., 72: 471-487.

Pearse, A. G. E., and S. Van Noorden 1963 The functional cytology of the human adenohypophysis. Canad. Med. Assoc. J., 88: 462-471.

Purves, H. D., and E. G. Bassett 1963 The staining reactions of the pars anterior cells. In: Cytologie de l'adenohypophyse. Ed. by J. Benoit and C. Da Lage. Paris. Editions of C.N.R.S., pp. 231-242.

Romeis, B. 1940 Innerskretonische Drusen II. Hypophyse. In: Handbuch der Microskipischen Anatomie des Menschen. Ed. by W. von Mollendorf, Julius Springer, Berlin.

Swanson, H. E., and C. Ezrin 1960 The natural history of the human adenohypophysis: in childhood, adulthood, and pregnancy. J. Clin. Endocr., 20: 952-966. 


\section{PLATE 1}

\section{EXPLANATION OF FIGURES}

1 The junctional zone between the pars distalis (PD) and pars nervosa $(\mathrm{PN})$. Anterior zone (AZ) and posterior zone (PZ) of the pars distalis. The dark areas (upper center) are colloid-filled remnants of the residual cleft. Aldehyde fuchsin and Masson. $\times 200$.

2 An oval, type III cell. Note the prominent nucleolus and coarse cytoplasmic granules. Interference green filter. Alcian blue-PAS-orange G. $\times 2000$,

3 A type III cell. Observe the abundant cytoplasmic granules. Colloidal iron-PAS-orange G. $\times 23000$.

4 A round, type III cell. Note the coarseness of the cytoplasmic granules. Aldehyde thionin-PAS-orange G. $\times 2300$.

5 A partially degranulated type III cell. Aldehyde fuchsin and Masson. $\times 2000$.

6 A modified type III cell. Cytoplasmic granules are present only in the juxtanuclear area. Aldehyde fuchsin and Masson. $\times 2000$.

7 A degranulated type III cell. Herlant tetrachrome. $\times 2000$. 

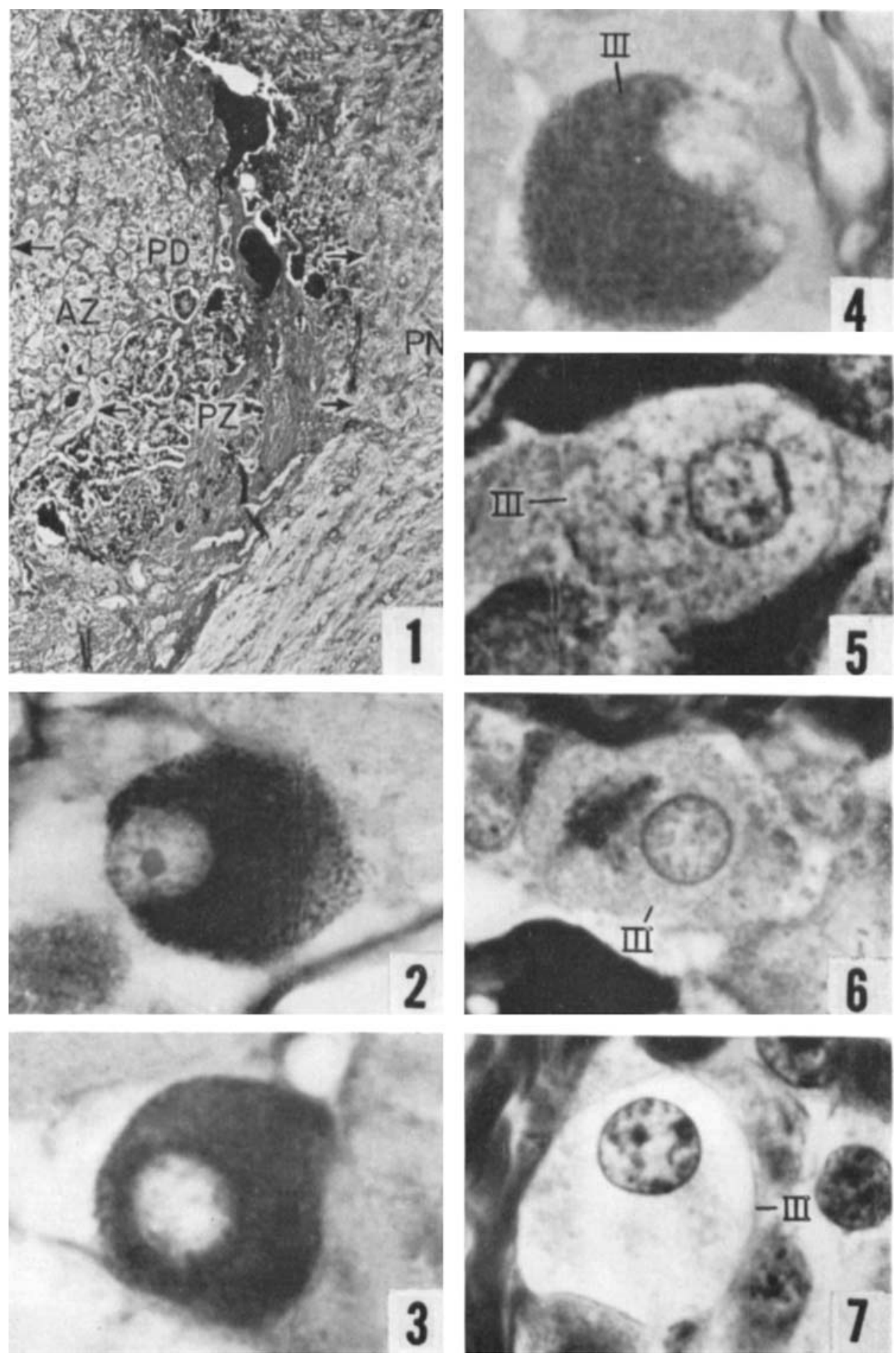


\section{PLATE 2}

EXPLANATION OF FIGURES

8 An intensely granulated, oval, type IV cell. Alcian blue-PAS-orange G. $\times 2000$

9 A round, type IV cell. Alcian blue-PAS-orange G, $\times 2000$.

10 A cytoplasmic vesicle (V) in a type IV cell. Alcian blue-PAS-orange G. $\times 2000$.

11 A field of type $V$ cells. Note the differences in their appearance when contrasted with figures 12-14. Interference green filter. Aldehyde fuchsin and Masson. $\times 1600$.

12 A type $\mathrm{V}$ cell exhibiting light cytoplasmic staining. Herlant tetrachrome. $\times 2000$

13 A type $\mathrm{V}$ cell. Note the coarse, darkly stained droplets or vesicles in the cytoplasm. Aldehyde thionin-PAS-orange G. $\times 2000$.

14 A typical type $\mathrm{V}$ cell. Note the difference in the appearance of the cytoplasm when compared with the cell in figure 13. Alcian bluePAS. $\times 2000$.

15 Two oval type VI cells. Note the density and size of the cytoplasmic granules. A nuclear counterstain was not employed. Aldehyde thionin PAS-orange G. $\times 2300$. 
PITUITARY MUCOID CELLS

PLATE 2

James L. Conklin
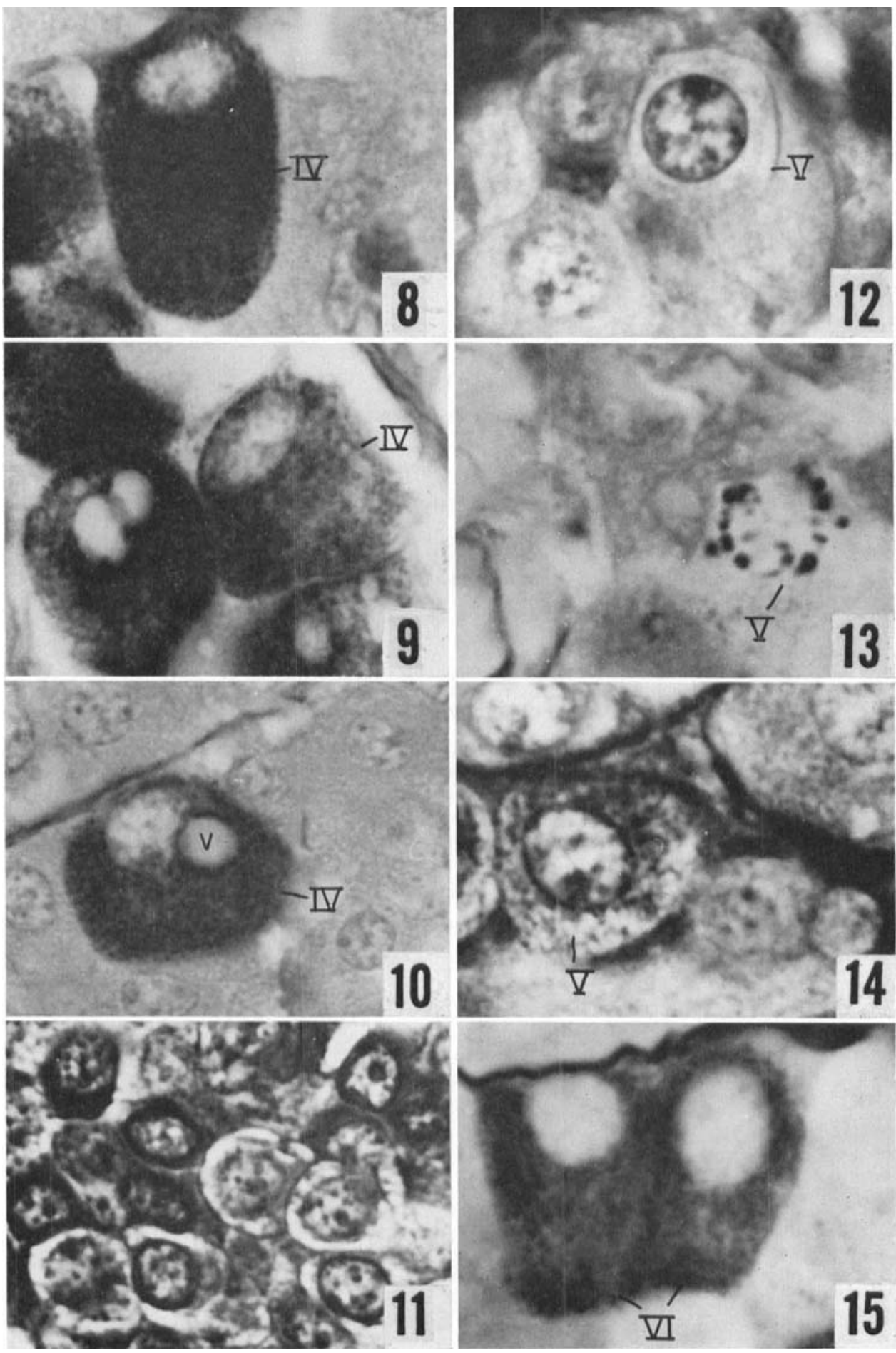
PLATE 3

EXPLANATION OF FIGURES

16 A round type VI cell. Aldehyde thionin-PAS-orange G. $\times 2300$.

17 A vacuolated type VI cell. Interference green filter. Herlant tetrachrome. $\times 2000$.

18 A partially degranulated type VI cell. Note the centrioles in the juxtanuclear area. Herlant tetrachrome. $\times 2000$.

19 Prominent, stained vesicles in a degranulated type VI cell. Aldehyde fuchsin and Masson. $\times 2300$.

20 A mixture of cell types. Observe the weak staining of the type IV cell. Also note the intensity of staining and the variable morphology of the cells. Aldehyde thionin ${ }^{1}-\mathrm{PAS}-\mathrm{orange} \mathrm{G}, \times 1400$.

21 A binucleated type III cell and a small type VI cell. Note the similarity in the staining intensity of the granules in the two cells. Aldehyde thionin ${ }^{2}$-PAS-orange G. $\times 2000$. 

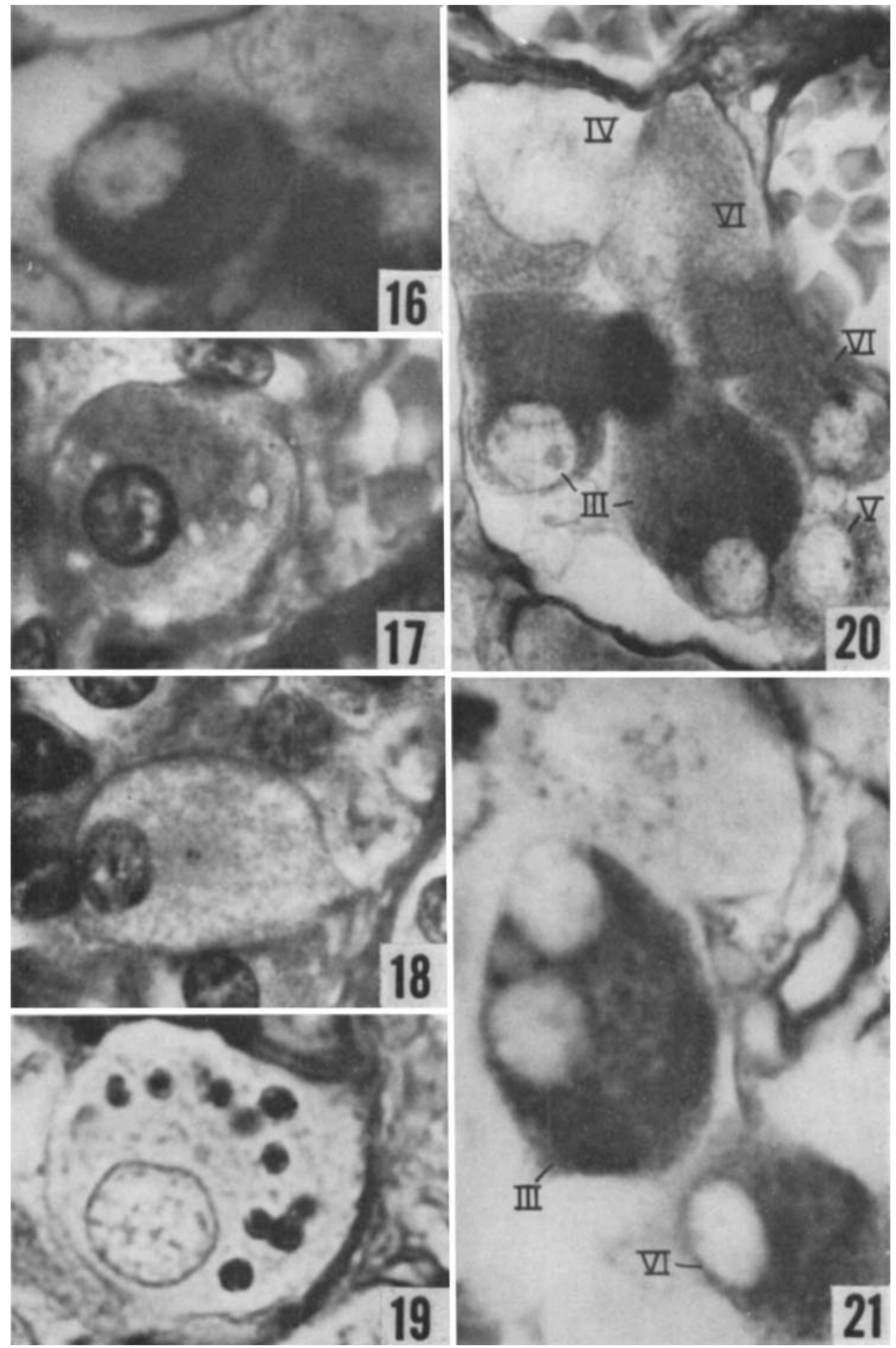
PLATE 4

EXPLANATION OF FIGURES

22 A variety of cell types. Note that the three different cell types exhibit slight differences in staining intensity while morphologic differences are not pronounced. Alcian blue-PAS-orange G. $\times 1600$.

23 This field was photographed without a filter. Contrast with figure 25 which is of the same field. Differences in the staining of cytoplasmic granules are not apparent in this figure (23). Alcian blue-PAS. orange G. $\times 1600$.

24 Cell types IV and VI. The use of a Wratten no. 22 filter illsutrates the difference between the granules of the two cell types. Alcian blue-PAS-orange $\mathrm{G} . \times 1600$.

25 Cell types III and VI photographed through a Wratten no. 22 filter. Note the contrast in the intensity of the granules in the two cell types. (See fig. 23.) Alcian blue-PAS-orange G. $\times 1600$. 

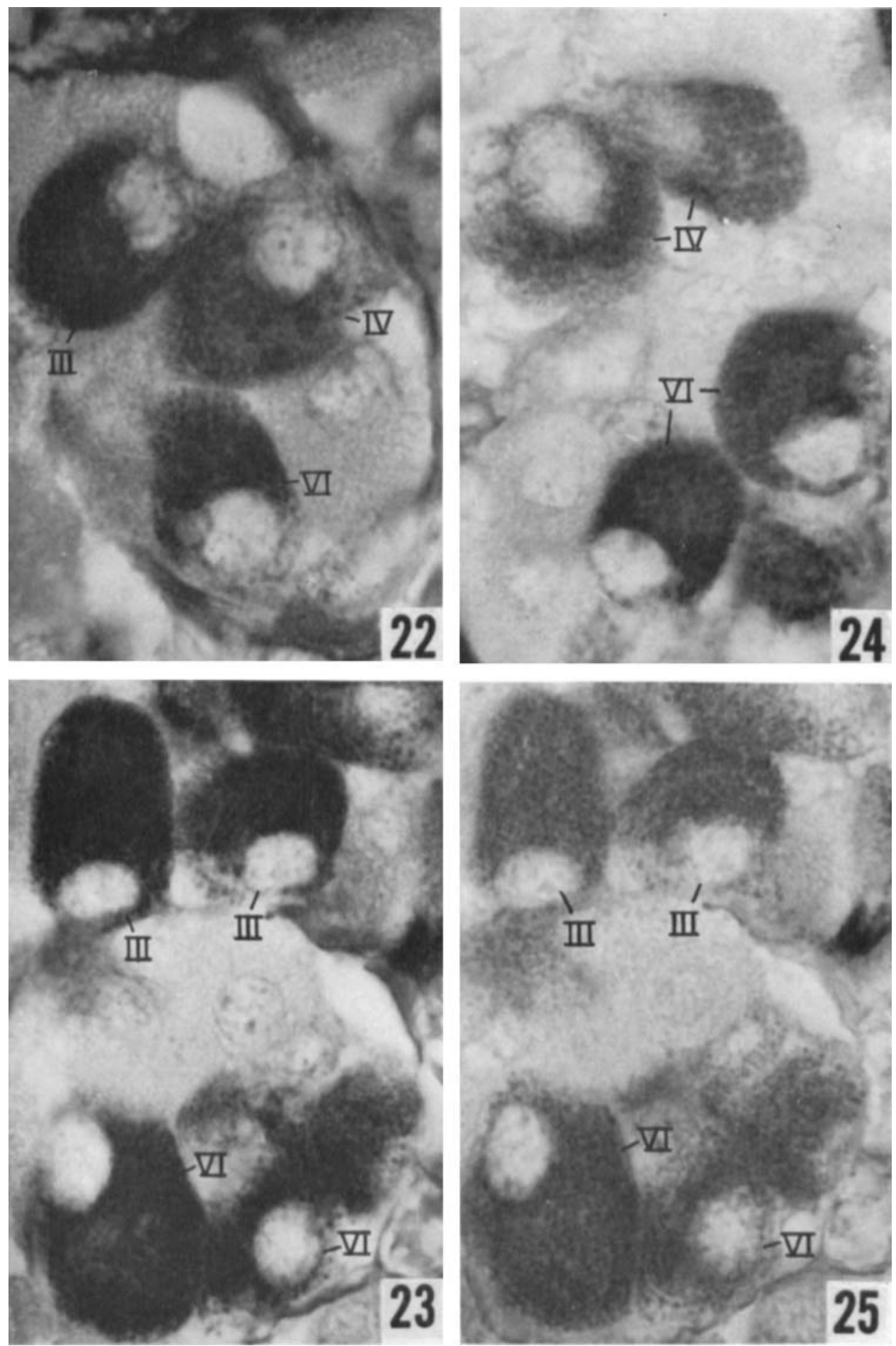
PLATE 5

EXPLANATION OF FIGURES

All figures are of cells in the posterior zone of the pars distalis.

26 The type III cell is degranulated. Contrast the type IX cell in this and figures 27-28. The poor cellular detail is the result of the poor cellular preservation in this arca. Aldehyde fuchsin and Masson. $\times 1400$.

27 A mixture of cell types. The more intense staining of the type IX cell is apparent in this field. Alcian blue-PAS-orange G. $\times 1600$.

28 The type IV cell is a modified type. Aldehyde thionin-PAS-orange G. $\times 1600$.

29 The type III cell is a modified type. Aldehyde fuchsin and Masson. $\times 2300$. 
PITUITARY MUCOID CELLS

PLATE 5

James L. Conklin
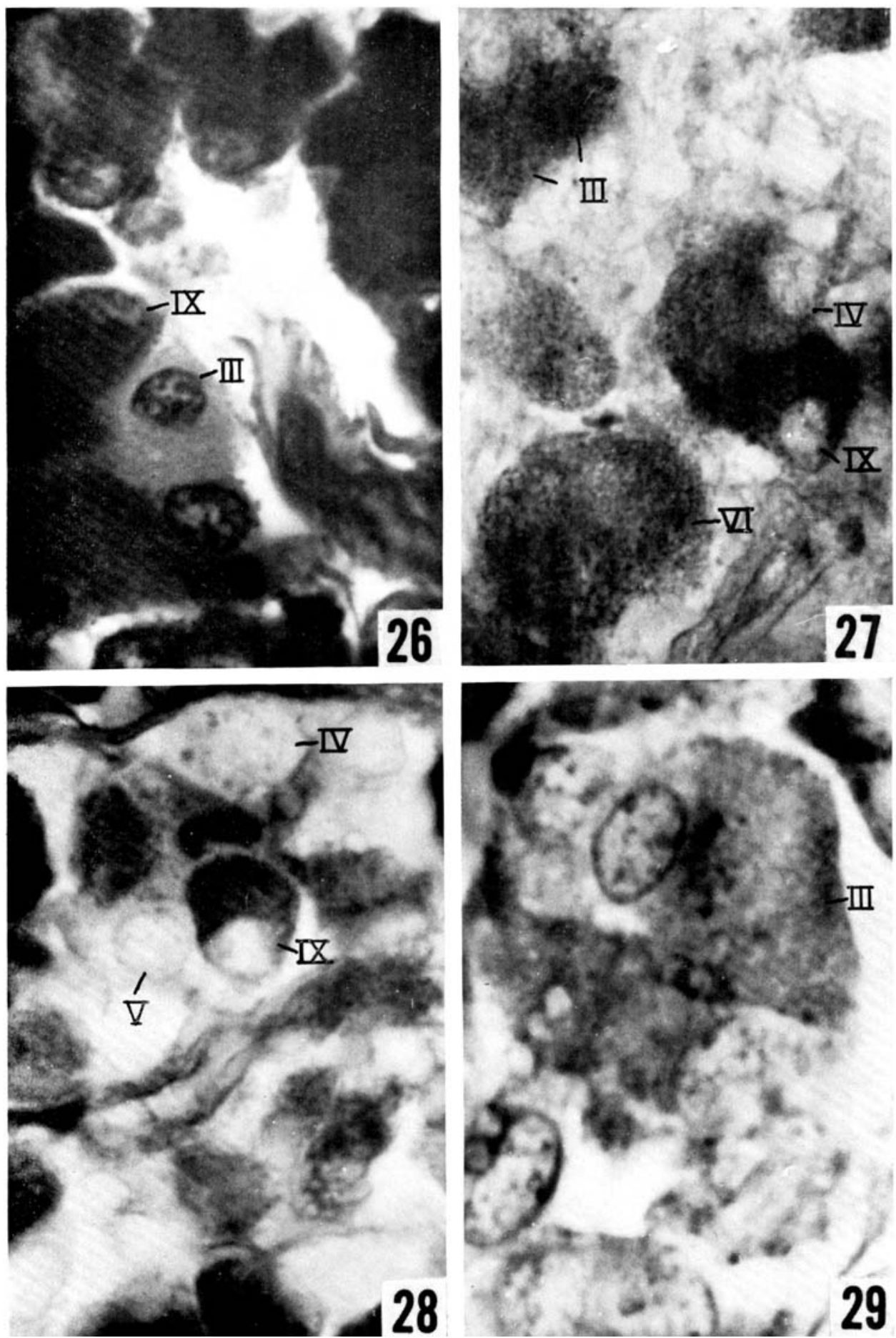